\title{
Nadir bir kronik diyare nedeni: Mantle Cell lenfoma ve eşlik eden multiple myelom olgusu
}

\author{
A rare cause of chronic diarrhea: a case of mantle cell lymphoma associated with multiple myeloma \\ Işılay NADIR ${ }^{1}$, Cansel TÜRKAY'1 ${ }^{1}$, Meral SÖZEN ${ }^{1}$, Özlem BALÇIK², Sibel YENIDÜNYA ${ }^{3}$, Ali KOŞAR \\ Fatih Üniversitesi Tıp Fakültesi, ${ }^{1}$ Gastroenteroloji Bilim Dalı, ${ }^{2}$ Hematoloji Bilim Dalı ve ${ }^{3}$ Patoloji Ana Bilim Dalı, Ankara
}

Kolon ve rektum malign lenfomaları nadir olup, adenokarsinom ve karsinoid tümörlerden sonra görülmektedir. Bu makalede kronik diyare nedeni ile başvuran ve mantle cell lenfoma ile eş zamanlı multiple myelom tanısı almış olan vakayı literatür bilgileri eşliğinde sunduk.

Anahtar kelimeler: Kronik diyare, mantle cell lenfoma

\section{GİRİş}

Kolon ve rektumda malign lenfomaların görülme sıklı̆̆ı, adenokarsinom ve karsinoid tümörlerden sonra üçüncü sırada yer alır. Tüm gastrointestinal sistemde malign lenfomaların oranı \%1-4 iken, bu oran kolonda \%0.05'dir (1).

Bu makalede sunacağımız olgu kronik diyare nedeni ile yapılan kolonoskopi sonucu mantle cell lenfoma (MHL) ve tanisı almış olup daha sonra kemik iliği biyopsisi ile de eş zamanlı multiple myeloma (MM) tanısı konulduğundan sunuma uygun bulunmuştur.

\section{OLGU}

Altmışdokuz yaşında kadın hasta on aydır günde 6-7 kez olan ishal, karın ağrısı ve gaz şikayetiyle gastroenteroloji polikliniğine başvurdu. Son 4 ayda 10 kilo kaybı olan hasta ishalinin aralıklı olarak kanlı olduğunu ve ateşinin 37 dereceye çıktığını ifade etti. Fizik muayenesinde $38{ }^{\circ} \mathrm{C}$ derece ateş saptandı. Laboratuvar incelemelerinde Hgb: 10g/dl, albumin: $2.8 \mathrm{~g} / \mathrm{dl}$, sedim: 78mm/h ve CRP: $96 \mathrm{mg} / \mathrm{L}$ ile patolojik değerlerde saptand. Kronik diyaresine yönelik yapılan gaita mikroskopisi, gaitada parazit incelemeleri normal saptandı. Bir yıl önce tarama amacı ile kolonoskopi yapılan ve normal olduğu öğrenilen hastaya tekrar yapilan total kolonoskopide rektum ve sigmoid kolonda ödemli, yaygın hiperemik ve dokunmakla frajil mukoza izlendi. Ayrica sigmoid kolonda mukozadan kabarık $1 \mathrm{~cm}$ çaplı polipoid lezyon ve bu lezyonun proksimalinde üzeri eksuda ile kaplı $1.5 \mathrm{~cm}$ çaplı ülsere lezyon izlendi (Resim 1). Lezyonlardan alınan biyopside atipik lenfoid infiltratlar saptandı. Bulguların öncelikle mantle cell lenfomayı düşündüreceği belirtildi. Immünhistokimyasal incelemede CD5,
The colon and rectum are rare sites of malignant lymphoma, observed in frequency after adenocarcinoma and carcinoid tumors. In this article, a case with mantle cell lymphoma presenting with chronic diarrhea and with a simultaneous diagnosis of multiple myeloma is presented together with a review of the related cases in the literature.

Key words: Chronic diarrhea, mantle cell lymphoma

CD20, Ig M, CD 22, siklin D1 ile pozitif boyandı (Resim 2,3). $\mathrm{Bu}$ bulgular ile mantle cell lenfoma tanisı konulan hasta hematoloji ile konsülte edildi. Periferik LAP olmayan hastaya hematoloji kliniğinde evreleme amaçlı kemik iliği biyopsisi ve pozitron emisyon tomografi (PET-CT), yapıldı. Kemik iliğinde lenfoma infiltrasyonu izlenmezken, \%30 oranında monoklonal plazma hücresi artışı tesbit edildi. Olguya MHL ile birliktelik gösteren MM tanısı konuldu.

\section{TARTISMA}

Kronik ishal gastroenteroloji polikliniklerine sık başvuru nedeni olan semptomlardan biridir. İritabl barsak sendromu, inflamatuvar barsak hastalığı, mikroskobik kolit, malabsorbsiyon sendromları, kronik enfeksiyonlar ve ilaçlar başlıca kronik ishal nedenidir (2)

Primer kolon lenfoması nadir bir durumdur. Kolonda polipoid ya da infiltratif ve kaviter lezyon olarak görülür. En yaygın

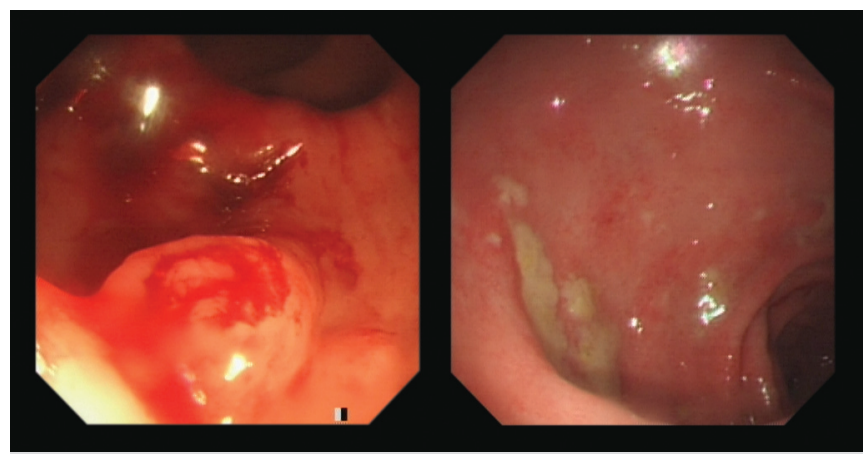

Resim 1. Kolonoskopide mukozadan kabarnk polipoid lezyon ve ülsere lezyon. 

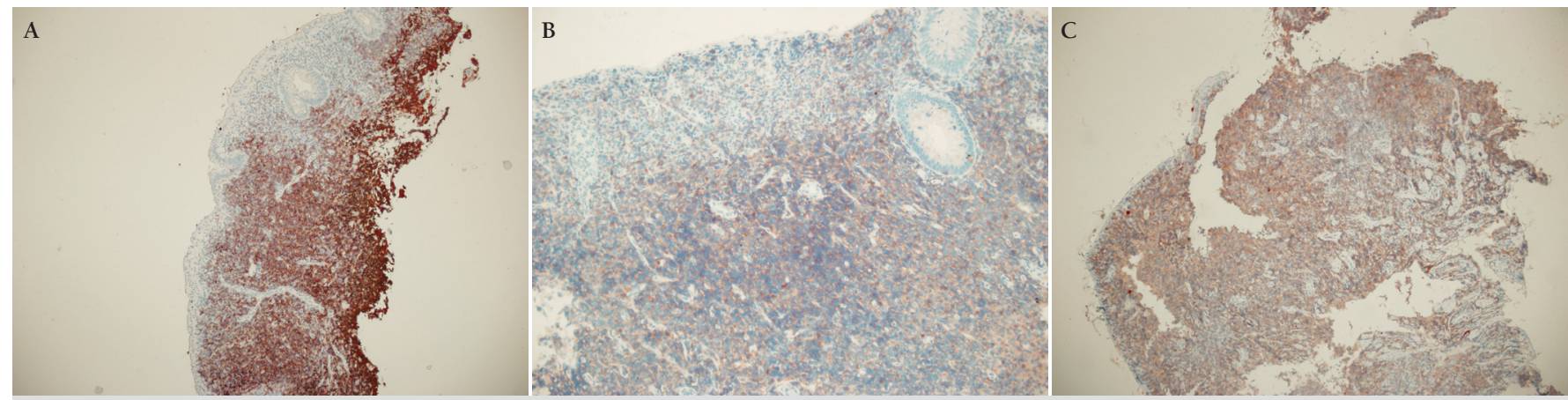

Resim 2. Immünhistokimya ile CD 20 (A), CD 5 (B), Ig M (C) pozitifliği.

klinik bulgular karın ağrısı (\%90), abdominal kitle (\%80), kilo kaybı (\%45), diyare, ateş, iştahsızlık olarak sayılabilir. Obstrüksiyon \%20-25 oranında, perforasyon ise daha az sıklıkta görülür. Klinik olarak inflamatuvar barsak hastalığını taklit edebilir, hatta birlikte bulunabilir (3). Bizim hastamız karın ağrısı, subfebril ateş ve kronik diyare ile başvurmuş olup, kolonoskopide aktif kolit düşünüldü. Biyopside atipik lenfoid infiltrat görülmesi üzerine immünhistokimya ile MHL tanısı aldi.

Mantle cell lenfoma, non Hodgkin lenfomaların \%7'sini ve gastrointestinal lenfomaların \%20'sini oluşturur. CD5, CD20, siklin D1 eksprese eden küçük-orta çaplı lenfosit proliferasyonu ile karekterizedir. MHL morfolojik açıdan diğer düşük dereceli lenfomalara benzemesi nedeni ile, 1990'lara kadar yavaş seyirli bir lenfoma olarak kabul edilmiştir. Daha sonra- ları ise, hastalık için bir belirteç olarak kabul edilen BCL1 onkojeninin bulunması ve hastalık biyolojisi üzerine yapılan yoğun çalışmalar, bu özel lenfoma türünün küçük lenfositik ve küçük çentikli hücreli lenfomalar ile bir ilişkisi bulunmadığ1nı ve daha agresif seyirli olduğunu göstermiştir $(4,5)$.

Hastamıza daha sonra hematolojik evreleme amacıyla yapılan kemik iliği biyopsisinde ise MM saptanmıştır. İki ayrı matür B hücre neoplazisinin birlikteliği literatürde nadirdir.

MM ve MHL differansiye klonal B hücre neoplazmlarıdır. Sık olmayarak her iki hastalık aynı anda görülebileceği gibi MM seyrinde MHL veya MHL seyrinde MM görülebilir.

Kronik ishal nedeniyle başvuran hastamızda kolonoskopik biyopside MHL tanısı konulması ve birlikte MM'nın eşlik etmesi nedeniyle vakamız ilginç olup sunuma uygun bulunmuştur.

\section{KAYNAKLAR}

1. Busch E, Rodrigez-Bigas M, Mamounas E, et al. Primary colorectal nonHodgkin's lymphoma. Ann Surg Oncol 1994; 1: 222-8.

2. Fine KD, Schiller LR. AGA technival review on the evaluation and management of chronic diarrhea. Gastroenterology 1999; 116: 1464-8.

3. Kella V, Constantine R, Parikh N, etal. Mantle cell lymphoma of the gastrointestinal tract presenting with multiple intussuscepttions. Case report and rewiev of the literature. World J Surg Oncol 2009; 7: 60.

4. Romaguera JE, Medeiros LJ, Hagemeister FB, et al. Frequency of gastrointestinal involvement and its clinical significance in mantle-cell lymphoma. Cancer 2003; 97:586-91.

5. Gaglia A, Foukas P, Polymeros D. Colonic involvement in a patient with mantle cell lymphoma. Clin Gastroenterol Hepatol 2010; 8: 99-100. 